\title{
Production potential and monetary efficiency of Indian mustard (Brassica juncea) in intercropping system under rainfed conditions of North-West Himalayas
}

\author{
Rayees A. Shah \\ National Agricultural Innovation Project, SRLS-3, KUPWARA(J \& K) INDIA
}

\begin{abstract}
A field experiment was conducted during winter (Rabi) season of 2011-12 and 2012-13 at actual line of control between India and Pakistan occupied Kashmir (ALC); in Teethwal block of district Kupwara (Jammu and Kashmir) to evaluate the production potential, biological feasibility and economic viability of intercropping of brown sarson (Brassica campestris) with wheat (Triticum aestivum L.), lentil (Lens culinaris Medikus), pea (Pisum sativum L.), potato (Solanum tuberosum L.), oats (Avena sativa L.) and also as sole crop. Brown sarson yield decreased in sole/monocropping and yield of mustard was inversely proportional due to intercropping with nonlegminous crops, whereas yield of mustard was in the order 11.26 and 11.85 q ha ${ }^{-1}$ during 2011-12 and 201213 seasons, respectively. yield components, viz., primary branches/plant, secondary branches/plant, pod/plant, seeds/pod and 1000 -seed weight $(\mathrm{g})$ of main crop of brown sarson also increased in the intercropping systems where component crops are legumes. Brown sarson with lentil or pea was most remunerative in respect of benefit : cost ratio. These intercropping systems showed higher brown sarson-equivalent yield, biological efficiency and monetary advantage among other intercropping systems.
\end{abstract}

Key Words : Brown sarson, Production, Monetary advantage, Intercropping

View Point Article : Shah, Rayees A. (2018). Production potential and monetary efficiency of Indian mustard (Brassica juncea) in intercropping system under rainfed conditions of North-West Himalayas. Internat. J. agric. Sci., 14 (1) : 112-117, DOI:10.15740/HAS/ IJAS/14.1/112-117.

Article History : Received : 20.07.2017; Revised : 16.11.2017; Accepted : 29.11.2017 